\title{
Voters (Dis)-Believing Digital Political Disinformation in Gubernatorial Election of DKI Jakarta 2016-2017
}

\author{
Gilang Desti Parahita \\ Department of Communication Studies, Faculty of Social and Political Sciences, Universitas Gadjah Mada \\ (Email: gilang_parahita@ugm.ac.id)
}

\begin{abstract}
Some studies, with regards to the salience of digital disinformation, have focused on investigating the tendency to believe disinformation by looking at a single cluster of factors. This study reveals factors ranging from multiple clusters, such as socioeconomic status, political partisanship, diversity of media exposure, trust in the media, and the digital fluency of the voters. The Gubernatorial Election of DKI Jakarta during 2016-2017 provided a context for examining the correlation between these factors and the (dis)-belief of digital political disinformation among the voters. In the election, the incumbent governor, Basuki Tjahja Purnama, was falsely accused of being a communist, which is still a dirty word in Indonesia, by his opponent. A survey was conducted for this research, collecting completed questionnaires from 191 citizens of DKI Jakarta who had voting rights and could access the online and digital disinformation. The null hypothesis was that socioeconomic status, political partisanship, diversity of media exposure, trust in the media and digital fluency did not influence the citizens' perceptions towards digital political information. However, the regression analysis found that the null hypothesis should be rejected. Of those predictors, political partisanship had the highest significant correlation with those perceptions.
\end{abstract}

\section{Keywords:}

political hoax; digital disinformation; political partisanship; trust in media; media exposure; digital fluency; local election

\section{Introduction}

In the age of information overload, not all political information is accurate and true. In the context of Indonesia, where the number of social media users is one of the highest globally, political hoax that is frequently viral through online, has derailed the quality of political processes in Indonesia, especially when national and local elections are approaching. Dis-informed and misinformed public make the wrong political decisions. Current regulations and fact checkers are unable to accelerate the speed of disinformation and misinformation penetration. As the audience could have stakes in spreading misinformation and disinformation, it is important to investigate what factors contribute to (dis)-believing digital disinformation.

There is not much research on the relation between several factors that might contribute to (dis)-believing disinformation; while, (dis)believing information is rarely supported only by one factor. Current studies mostly focus on assessing an audience's perception of information, by looking at a single predictor,

\footnotetext{
1 This research was funded by the Faculty of social and Political Sciences, Universitas Gadjah Mada, Yogyakarta, Indonesia.
} 
whether it lies in the side of audience, or the source of information. At the side of individual, some factors including demographic characteristics (Gaziano \& McGrath, 1985) and political partisanships (Feldman, 2011; Ladd, 2010; Schmitt, Gunther \& Liebhart, 2004) might relate to the judgment of audience towards the credibility of news sources. Apart from social and political backgrounds, some studies recognized the importance to consider the roles of scepticism and cynicism of an audience in perceiving news (Lee, 2005; Lee, 2010), while others ask why audiences keep watching news they distrust (Tsfati \& Cappella, 2005). On the other hand, at the medium side, trusted information might be related to the medium type and the storytelling structure (Fico, Richardson \& Edwards, 2004), topical salience in news (Watts et al., 1999), source and apparent quality (Austin \& Dong, 1994; Burgess, et al., 2011), and user-generated content in the form of comments (Houston, Hansen, \& Nisbett, 2011). Because of the inclination of existing research using a single-category of predictor, this research intends to reveal that several factors might predict the tendency of voters in (dis)-believing disinformation. Those factors are socioeconomic status, political partisanship, diversity of media exposure, trust in news media, and digital fluency of voters.

This research was conducted within the context of DKI-Jakarta's gubernatorial election in 2016-2017. ${ }^{2}$ The reason behind choosing DKIJakarta's election is the citizens of DKI Jakarta represent the diversity of Indonesian people. In

\footnotetext{
2 Incumbent governor Basuki Tjahja Purnama or Ahok became a candidate in pair with Djarot Saiful Hidayat. Besides the pair, other two pairs of candidates were nominated in the election. Other pairs were Anies Rasyid Baswedan and Salahuddin Uno (Anies-Sandi) and Agus Harimurti Yudhoyono-Sylviana Murni (Agus-Sylvi). Anies-Sandi were supported by Great Indonesia Movement Party (Partai Gerindra) and Prosperous Justice Party (PKS). Agus-Sylvi were supported by Democratic Party (Partai Demokrat), the United Development Party (PPP), National Mandate Party, and National Awakening Party (PKB).
}

the mean time, they might also epitomise the low levels of Indonesian trust in news media, as well as insufficient digital fluency (Edelman, 2017; Accenture \& Femina, 2017). When this article was written, the Ministry of Communication and Information (Kominfo) stated that they would impose a policy allowing Kominfo to regularly announce a hoax through its website (Hutabarat, 2018). This government's plan represents that the negative impact of disinformation in Indonesia is already at an alarming rate, and digital fluency of Indonesians is deemed low.

Secondly, digital disinformation spread during the campaign phase of DKI Jakarta gubernatorial election. One of the hoaxes was Basuki Tjahaja Purnama (nicknamed Ahok), the incumbent governor of DKI Jakarta in 2016; he was linked to the threat of Chinese invasion and the revival of communism, and was repeatedly accused to be a communist, a term that remains unpleasant in Indonesia (Vltchek, 2017; Kwok, 2017; Kato, 2017). Eventually, Ahok and Djarot lost to Anies Baswedan (Anies) and Sandiaga Uno (Sandi) in the second round. ${ }^{3}$ Ahok's success team and political observers believed that the loss of Ahok was related to religious and ethnic sentiment, which is traceable

\footnotetext{
3 Pair of Agus-Sylvi lost in the first round. Some considered the loss of Agus-Sylvi was due to the excessive intervention of Harimurti's father, Susilo Bambang Yudhoyono, the former President of Indonesia. The intervention concealed the independence and leadership potentials of Harimurti. In the second round, Anies-Sandi defeated Ahok-Djarot. The election went in two rounds. The loss of Ahok-Djarot from Anies-Sandi in the second round was caused by the swing voters of Harimurti-Murni gave their votes to Anies-Sandi as both pairs have similar identity which is Islamist couples, in contrast to Ahok-Djarot.

However, it might also be true that the loss of Ahok was related to a blasphemy allegation posed to him. A doctored video of Ahok saying to a bunch of citizens in Jakarta's Thousand Islands (officially Kepulauan Seribu) Administrative Regency, which was "not to be 'fooled' by those who use Al Ma'idah verse 51 of the Quran", spread online, offended some Moslems, and stirred up controversy. Condemning the video, mass Islamic protests took place in Jakarta before the first round of election or since late October 2016. He was then put into trial and lost.
} 
since 2012 DKI Jakarta's election, when the sentiment of being "native" Betawi was salient and religious identity was confronted (Miichi, 2014; Nugroho, 2017; Novitasari, 2017; Setijadi, 2017). ${ }^{4}$ Thirdly, the salience of grassroot people in influencing the public discourse during DKI Jakarta's gubernatorial election in 2012 (Suaedy, 2014) shows that the online public who have vested interest in the election are relatively more active, in comparison with many other regions of Indonesia. ${ }^{5}$

Despite the dominating issues of ethnicity and religion sentiment in the case of 2016-17 DKI Jakarta's election, this research aims to uncover and compare several types of predictors, ranging from socioeconomic, political partisanships, media exposure diversity, trust in news media, and digital fluency, in their relations to (dis)believing digital disinformation. To know which factors actually contribute to making the voters more gullible to digital disinformation, this research conducted a survey to the citizens of DKI Jakarta who had voting rights.

\section{Factors Affecting (Dis)-Believing to Digital Disinformation}

Disinformation is not new in the sphere of politics because the phenomenon can be traced back to 1980s when information wars occurred and propaganda was used to generate power (Hutchinson, 2006). However, digital content in the forms of online articles, memes, and social media status are spread throughout multicentred online world and they bombard users without any guarantee

\footnotetext{
4 After Ahok - who is typically brash and bluntly speaking- was alleged for blasphemy, his electability rating plunged from $50 \%$ to below $25 \%$ in November 2016. His political opponents did not convict Ahok for blasphemy but they took advantage from the conservative Islamist sentiments (Setijadi, 2017).

5 The voluntary groups, benefiting from the capability of online technology, were able to mobilize the citizens to participate in the election and monitor the candidates, which was much different from money politicsdomination in local elections as usually found in other provinces in Indonesia, (Suaedy, 2014).
}

that the content has gone through the editorial selection as conventionally applied (Flanagin \& Metzger, 2000; Houston, Hansen, Nisbett, 2011). Therefore, digital content might contain jokes, obsolete information, factual mistakes, inaccuracies, rumours, gossips, conspiracies, slander, bias, and scientific malpractices (Fitzgerald, 1997; Qazvinian, et al., 2011; Renard, 2007; Thorson, 2016). Audience behaviour that becomes the success key of conventional media outlet which is "trust" could be counterproductive if it is applied to digital disinformation (Arpan \& Raney, 2003). Nichols, McKinnon \& Geary (2016) defined gullibility as how far the recipients value truthfulness of rumours. This research understands the gullibility of Nichols, McKinnon \& Geary (2016) as the tendency of people to believe or disbelieve in disinformation or deception. Gullible people to digital disinformation means people who tend to evaluate any types of digital disinformation as true and correct.

\section{Socioeconomic Status}

Audience research has started to consider differences in social economic background when Katz and Liebes in the 1980s stated that media messages were interpreted distinctively by different social groups (Mahtani, 2008). Some research implemented socio economic factors to predict an audience's trust and mistrust of news media (Lee, 2010) and the use of traditional and new media (Tran, 2013). Many other studies classify level of income and education, household size, also status of employment into the term of socioeconomic status (Wiliams et al., 1997; Shatz, et al., 2003; Ritzhaupt et al., 2013). In the context of DKI Jakarta's election, socioeconomic status was comprised of levels of income, and education.

\section{Political Partisanship}

Scholars have proposed several meanings of partisanship, but this research addresses partisanship as political support, affinity 
and identification of oneself towards certain political stand. Although it does not need to be expressed formally as party membership, it shows commitment (White \& Ypi, 2011; Sheth, 1971). Some research has shown an influential relationship between partisanship and information processing (Enns \& McAvoy, 2012). The tradition of Hostile Media Effect theory believes that an audience's evaluation towards news content credibility depends on one self's prior-judgment to the media. Therefore, if oneself thinks that one news media is subjective, a person will see the following news content as bias too (Schmitt, Gunthe, \& Leibhart, 2004; Lee, 2005; Feldman, 2011). In reverse, people with political partisanship might trust digital disinformation congruent to their political beliefs. This research defines the political partisanship as self-identification to party, political views, and satisfaction to incumbent leaders. Political partisanship in this research was investigated by looking to the opinions of the voters on the religion and leadership of Ahok as a governor. Rising religious intolerance in Indonesia, echoed by radical Moslem groups, prevented ChristianChinese Ahok gaining sympathy from voters, as it is said that Moslems should not elect nonMoslem politicians (Kato, 2017). Administrative achievement of non-Moslem leaders could then suffer from "religious bias" of the voters.

\section{Diversity of Media Exposure}

Media exposure is the quality of audience exposed by media content or messages, whether remembered well or not (Vreese \& Neijens, 2016). It includes what part of media content they can recall, their recognition of media content, attention to media content and messages, the frequency of exposure, and even their involvement in media such as sharing, liking, forwarding and participation (Vreese \& Neijens, 2016). Types of media content are factual information, entertainment, commercial and opinion (Flanagin \& Metzger, 2000).
Some research has observed a relationship between media exposure and audience behaviour. Thus, Tsfati (2010) found a positive relationship between scepticism and mistrust to mainstream media with the frequency of alternative online sites. Williams (2012) has proved that an audience's belief of media influences their media use, selective exposure, and selective attention. In the context of new media, cognitive dissonance theory has reemerged as a new media environment allowing users to select online content that serves their existing beliefs to avoid discomfort and cognitive dissonance and the theory supports homophile/ heterophily paradigm (Shin et al., 2016; Jang, 2013).

This research investigated the tendency of media exposure diversity factor influencing the trust in digital disinformation. It examined the perception of media diversity (its type, political stances of news media, online formats), involvement in political information, and homophily/ heterophily in news and social media.

\section{Trust in News Media}

Since the 1970s, scholars have investigated how audiences perceive source (personal, organizational, mass media) and medium (print, electronic, online) credibility (Kiousis, 2001). Williams (2012) proposed trust in media and categorized it as trust in information and media institution. Metzger et al. (2003) defined trust in news media as how the public perceives media credibility, which includes accuracy, fairness, completeness, reliability and trustworthiness. Trust in media mostly refers to media credibility theory; while it can also mean trust in specific selectivity more than in objectivity and truth (Kohring \& Matthes, 2007). It assumes that when people trust in news media, they actually believe in specific selection offered by the news media. This research takes the stance of Kiousis (2001) and examines types of media (print, electronic, or online). 


\section{Digital Fluency}

Digital fluency has become the basic skill that people in $21^{\text {st }}$ century should have. It is the skill, knowledge framework, contemporary fluency and competence needed to assess, evaluate, value, synthesize, analyze and interpret the information's bias and integrity in the context of digital technology (Miller \& Bartlett, 2012). It consists of basic knowledge about information and communication technologies-especially net savviness, skill to evaluate critically, and depth and diversity of accessed and absorbed information components (Miller \& Bartlett, 2012). Some research investigated the predictors of digital fluency (Bologa, Lupu \& Saba, 2007; Wang, 2012), and the role of digital fluency in identifying digital age skills gap (White, 2013). In this research context, digital fluency might affect people's trust in (dis)-information.

\section{Research Question \& Hypotheses}

Based on previous theoretical foundation, this research poses a main question which is: what are the influential factors which affect the voter's trust in digital disinformation? This research investigates factors (independent variable/IV) affecting (dis)-believing in digital political disinformation (dependent variable/ DV) at the individual level. It consists of socioeconomic status, political partisanship, diversity media exposure, trust in news media and digital fluency.

H0 Socioeconomic factor does not affect the trust of the public in digital disinformation.

H1 Socioeconomic factor significantly affects the trust of the public in digital disinformation.

H0 Political partisanship factor does not affect the trust of the public in digital disinformation.

H1 Political partisanship factor significantly affects the trust of the public in digital disinformation.
H0 Diversity of media exposure factor does not affect the trust of the public in digital disinformation.

H1 Diversity media exposure factor significantly affects the trust of the public in digital disinformation.

H0 Trust in media factor does not affect the trust of the public in digital disinformation.

H1 Trust in media factor significantly affects the trust of the public in digital disinformation.

H0 Digital fluency does not affect the trust of the public in digital disinformation.

H1 Digital fluency factor significantly affects the trust of the public in digital disinformation.

What did not have to be answered in this research was whether gender or religion category has a significant correlation with perception to digital disinformation. Both categories were investigated limitedly to recognize their distributions across the sample.

\section{Methods}

Data collection was conducted by three enumerators with the assistance of Suveymonkey.com. As the questionnaires came in digital form, three enumerators were able to distribute its link and watch the feedback from 60-70 respondents from the population. The population is DKI Jakarta citizens who have valid DKI Jakarta ID-Cards and eligibility for voting in 2016-2017 whether they used their rights or not. The survey was launched online from 15 to 25 July 2017. The enumerators directly visited citizens in some districts and shared the questionnaire link to them, which then went viral and was able to cater 100 respondents within the first five days. The link was closed on the tenth day when the virality of the link declined and was fulfilled by 231 citizens of DKI Jakarta. However, only 191 
Table 1.

Numbers of Population and Sample in Six Districts of DKI Jakarta

\begin{tabular}{clcccc}
\hline No. & \multicolumn{1}{c}{ Districts } & $\begin{array}{c}\text { Population } \\
\mathbf{( 0 0 0 ~} \mathbf{~ p p l )}\end{array}$ & $\begin{array}{c}\text { Percent of } \\
\text { Population }\end{array}$ & Sample & $\begin{array}{c}\text { Percent of } \\
\text { Sample }\end{array}$ \\
\hline 1 & Central Jakarta & 913.87 & 9.00 & 16 & 8.4 \\
2 & East Jakarta & $2,826.66$ & 27.84 & 69 & 36.1 \\
3 & South Jakarta & $1,283.90$ & 21.51 & 50 & 26.2 \\
4 & West Jakarta & $2,293.00$ & 24.23 & 24 & 12.6 \\
5 & North Jakarta & $1,745.82$ & 17.19 & 31 & 16.2 \\
6 & Thousand Islands & 23.31 & 0.23 & 1 & 0.5 \\
7 & DKI Jakarta & $10,154.34$ & 100 & 191 & 100 \\
\hline
\end{tabular}

Source: SUPAS 2015

Table 2.

Gender of Respondents (N=191)

\begin{tabular}{clcccc}
\hline & & Frequency & Percent & Valid Percent & Cumulative Percent \\
\hline \multirow{3}{*}{ Valid } & Male & 93 & 48.7 & 48.7 & 48.7 \\
& Female & 98 & 51.3 & 51.3 & 100.0 \\
& Total & 191 & 100.0 & 100.0 & \\
\hline
\end{tabular}

Source: Research Data

Table 3.

Age of Respondents ( $\mathrm{N}=191)$

\begin{tabular}{ccccc}
\hline Age & Frequency & Percent & Valid Percent & Cumulative Percent \\
\hline $18-31$ & 131 & 68.6 & 68.6 & 68.6 \\
$32-46$ & 55 & 28.8 & 28.8 & 97.4 \\
$47-61$ & 5 & 2.6 & 2.6 & 100 \\
Total & 191 & 100 & 100 & \\
\hline
\end{tabular}

Source: research data

Table 4.

Religion of Respondents

\begin{tabular}{ccccc}
\hline Religion & Frequency & Percent & Valid Percent & Cumulative Percent \\
\hline Islam & 152 & 79.6 & 79.6 & 79.6 \\
Other & 39 & 20.4 & 20.4 & 100 \\
Total & 191 & 100 & 100 & \\
\hline
\end{tabular}

Source: research data

questionnaires fully completed an online via Surveymonkey.com.

Based on the data (Table 1.), most respondents were from East Jakarta (36.1\%) and South Jakarta (26.2 \%). North Jakarta and West Jakarta shared almost the same percentages of respondents ( $16.2 \%$ and $12.6 \%)$. The smallest percentage of respondents is from
Thousand Islands (0.5\%). It already represents the population of DKI Jakarta as reported by SUPAS 2015. The gender distribution was also consistent with SUPAS 2015 data, which shows a balance proportion between male and female (Table 2.).

The respondents are mostly aged 1831, followed by 32-46 then 47-61 (Table 3.). 
Table 5.

Independent Factors

\begin{tabular}{|c|c|c|}
\hline Factor & Indicator & Questions \& Responses \\
\hline \multirow{7}{*}{$\begin{array}{l}\text { Socioeconomic } \\
\text { Status }\end{array}$} & Level of Religiosity & Very low, Low, Average, High, Very High \\
\hline & Level of Education & Elementary School Drop Out \\
\hline & & Elementary/ Secondary School \\
\hline & & Tertiary School \\
\hline & & Diploma/ Undergraduate Education \\
\hline & & Postgraduate Education \\
\hline & $\begin{array}{l}\text { Level of Income in } \\
\text { Family }\end{array}$ & Very low, Low, Average, High, Very High \\
\hline \multirow[t]{2}{*}{$\begin{array}{l}\text { Political } \\
\text { Partisanship }\end{array}$} & Political Attitude & $\begin{array}{l}\text { The religion of the administrative leader of a region does not always } \\
\text { represent the majority religion in the area. } \\
\text { Strongly Disagree, Disagree, Neutral/No Opinion, Agree, Strongly Agree }\end{array}$ \\
\hline & $\begin{array}{l}\text { Satisfaction to } \\
\text { Incumbent Leaders }\end{array}$ & $\begin{array}{l}\text { Leadership of Basuki in economy, public health service and education. } \\
\text { Strongly Dissatisfied, Dissatisfied, Neutral/No Opinion, Satisfied, Very } \\
\text { Satisfied }\end{array}$ \\
\hline \multirow{10}{*}{$\begin{array}{l}\text { Diversity } \\
\text { of Media } \\
\text { Exposure }\end{array}$} & Diversity of media & I access a diverse media platform (print, electronic, online). \\
\hline & platform, media's & I access news content with diverse political stands. \\
\hline & political stands, and & I access political news that has different political opinions to mine. \\
\hline & diverse online content. & $\begin{array}{l}\text { I access various online content such as popular news, political opinions } \\
\text { and Islamic articles. }\end{array}$ \\
\hline & & Strongly Disagree, Disagree, Neutral/No Opinion, Agree, Strongly Agree \\
\hline & Involvement in & I share political news online to my social media network. \\
\hline & Political Information & Never, Sometimes, Average, Often, Always \\
\hline & Homophily/ & I always maintain online relationships in social media even if I have \\
\hline & Heterophily in social & different political stands with them. \\
\hline & media & Strongly Disagree, Disagree, Neutral/No Opinion, Agree, Strongly Agree \\
\hline \multirow[t]{3}{*}{ Trust in media } & Credibility of Media & I trust news media in the form of: \\
\hline & Types & Magazine, dailies, television, radio, online. \\
\hline & & Strongly Disagree, Disagree, Neutral, Agree, Strongly Agree \\
\hline \multirow[t]{2}{*}{ Digital Fluency } & Basic Knowledge & $\begin{array}{l}\text { I have knowledge on how to take online actions according to the } \\
\text { context. }\end{array}$ \\
\hline & & Strongly Disagree, Disagree, Neutral/No Opinion, Agree, Strongly Agree. \\
\hline
\end{tabular}

Source: Adapted from Tran (2013), Shin, et al.,( 2016); Jang (2013); Schmitt, Gunthe, \& Leibhart, (2004); Lee (2005); Feldman (2011); Miller \& Bartlett (2012); Kiousis (2001).

The divisions of the ages were based on the respondents inputs, in which the youngest was 18 and the oldest was 61 years old. The ages were then regrouped into three categories.

The respondents' religion was $79.6 \%$ Islam and the rest other religions (Table 4.). The categorisation of the religion was originally six religions as officially recognized in Indonesia. However, the data inputs showed that the numbers of respondents which belonged to five other religion groups were too insignificant to be analysed. Therefore, the data was recategorized into two divisions: Islam and other than Islam.

\section{Dependent Variable: (Dis)-Believe in Digital Political Disinformation (PD)}

The statement to test dependent variable is "I believe Ahok is a sympathizer of Indonesian Communist Party (PKI)."

Independent Variable (IV)/ Predictors: socioeconomic, political partisanship, media exposure, trust in media, $\mathcal{E}$ digital fluency factors

The tested factors are socioeconomic, partisanship, media exposure, trust in media, and digital fluency. Some of those factors use ordered-category scales (level of income in family, level of religiosity, political partisanship, diversity of media exposure, and digital 
fluency), and Likert scale (political partisanship; trust in media).

Political partisanship aspect consists of political identification, political attitudes, and satisfaction to incumbent leaders. Diversity of media exposure aspect investigates diversity of media platform, involvement to information and homophily. Trust in media aspect considers the trust of respondents to a variety of media platforms. Digital fluency examines the perception of respondents on how to use online features in different contexts.

To test the reliability of the data, Cronbach's Alpha is used to sample responses. The result shows 0.858 , which demonstrates high reliability as it is close to 1 .

Table 6.

\begin{tabular}{cc}
\multicolumn{2}{c}{ Reliability Statistics } \\
\hline Cronbach's Alpha & N of Items \\
\hline .858 & 33 \\
\hline
\end{tabular}

Source: Research Data

This study has some limitations. The study was conducted several months after the second round of gubernatorial elections of DKI Jakarta. Their perceptions toward political digital disinformation might have transformed before the survey was taken. It could be that they trusted them but their beliefs changed after the media clarified them. In addition, there was no question containing correct information about Basuki Tjahja Purnama to test the consistency and honesty of respondents' responses. However, respondents were asked about their perceptions on some online false information about Basuki and they had answered this consistently. Lastly, respondents' answers may not reflect their real attitudes and natural behaviour, as they only questioned them.

\section{Results}

Regression analysis is applied to socioeconomic, political partisanship, diversity of media exposure, trust in media and digital fluency towards online false information. Based on the data, adjusted $\mathrm{R}^{2}$ shows the extent of how influential the independent variables on the dependent variable are. Therefore, adjusted $\mathrm{R}^{2}$ are shown in Table 8 as .598 that means all independent variables (four variables) have an influence of around $60 \%$ on the dependent variable (DV), which is "Users' perception in online false information." Moreover, there is statistical significance with $\mathrm{p}$ values as shown in table 9 as 0.000 , which is less than 0.05 . This is the holistic statistics for the DV with all IVs and how they affect and influence the users' perceptions in online disinformation.

Table 7.

Model Summary of All IVs on DV

\begin{tabular}{ccccc}
\hline Model & $\mathbf{R}$ & R Square & $\begin{array}{c}\text { Adjust. R } \\
\text { square }\end{array}$ & Std. Error \\
\hline 1 & $.773^{\mathrm{a}}$ & .598 & .534 & .62757 \\
\hline
\end{tabular}

Source: Research Data

Note: Predictors: (Constant), Econ, Edu, Rel, PA, PP, PS, MD, IPI, TM, TT, TR, Tonline, DF.

Table 8.

ANOVA $^{a}$

\begin{tabular}{cccccc}
\hline Model & $\begin{array}{c}\text { Sum of } \\
\text { Squares }\end{array}$ & Df & $\begin{array}{c}\text { Mean } \\
\text { Square }\end{array}$ & F & $\begin{array}{c}\text { Sig. } \\
\text { (p value) }\end{array}$ \\
\hline Regression & 95.614 & 26 & 3.677 & 9.337 & $.000^{\mathrm{b}}$ \\
\hline
\end{tabular}

Source: Research Data

Note: Dependent Variable: (Dis)-Believe in Digital Political Disinformation (PD)

Predictors: (Constant), Econ, Edu, Rel, PA, PP, PS, MD, IPI, TM, TTV, TR, Tonline, DF

Statistical balances were conducted to IV's questions about political attitudes, political identity, and homophily/heterophily tendency. Statistically balanced statements show that the more respondents disagree to the statements, the less gullible they are. Meanwhile, other questions assume that the more they agree to the statements, the less they are gullible to online false information. DV's question was also balanced as the respondents who are less gullible should answer Disagree or 
Table 9.

Coefficients $^{\mathrm{a}}$

\begin{tabular}{|c|c|c|c|c|c|}
\hline \multirow{2}{*}{ Model } & \multicolumn{2}{|c|}{$\begin{array}{c}\text { Unstandardized } \\
\text { Coefficients }\end{array}$} & \multirow{2}{*}{$\begin{array}{c}\begin{array}{c}\text { Standardized } \\
\text { Coefficients }\end{array} \\
\text { Beta } \\
\end{array}$} & \multirow{2}{*}{$\mathrm{T}$} & \multirow{2}{*}{$\begin{array}{c}\text { Sig. } \\
\text { (p value) }\end{array}$} \\
\hline & B & $\begin{array}{c}\text { Std. } \\
\text { Error }\end{array}$ & & & \\
\hline (Constant) & $-.740-$ & .586 & & $-1.262-$ & .209 \\
\hline Religiosity & .106 & .079 & .077 & 1.349 & .179 \\
\hline Economic status & .113 & .090 & .071 & 1.249 & .214 \\
\hline Education & .099 & .082 & .072 & 1.214 & .227 \\
\hline $\begin{array}{l}\text { PA1: During all these years I have given my sympathy to } \\
\text { social organizations showing Islamic identity. }\end{array}$ & .118 & .078 & .116 & 1.523 & .130 \\
\hline $\begin{array}{l}\text { PA2: I have given sympathy to Islamic Defender Front } \\
\text { before the Election began. }\end{array}$ & .293 & .072 & .335 & 4.065 & .000 \\
\hline $\begin{array}{l}\text { PA3: I think the religion of a regional administrative } \\
\text { leader must represent the majority religion in the area. }\end{array}$ & $-.045-$ & .080 & $-.047-$ & $-.565-$ & .573 \\
\hline PP: I identify myself as a sympathizer of the Islamic party. & .028 & .088 & .020 & .320 & .749 \\
\hline PS1: Leadership of Basuki as Governor in education sector. & .113 & .065 & 136 & 1.740 & .084 \\
\hline $\begin{array}{l}\text { PS2: Leadership of Basuki as Governor in public health } \\
\text { service. }\end{array}$ & $-.038-$ & .087 & $-.036-$ & $-.441-$ & .660 \\
\hline PS3: Leadership of Basuki as Governor in economic sector. & .199 & .086 & .192 & 2.302 & .023 \\
\hline $\begin{array}{l}\text { MD1: I access diverse media platforms (print, electronic, } \\
\text { and online). }\end{array}$ & $-.041-$ & .086 & $-.036-$ & $-.477-$ & .634 \\
\hline MD2: I access news content with diverse political stands. & .048 & 107 & .040 & .455 & .650 \\
\hline $\begin{array}{l}\text { MD3: I access political news that has different political } \\
\text { opinions to my own. }\end{array}$ & .178 & .096 & .140 & 1.846 & .067 \\
\hline $\begin{array}{l}\text { MD4: I access various online content such as popular } \\
\text { news, political opinions and Islamic articles. }\end{array}$ & .053 & .082 & .045 & .653 & .515 \\
\hline IPI1: I comment on online news articles. & $-.135-$ & .072 & $-.140-$ & $-1.878-$ & .062 \\
\hline IPI2: I comment to status/post/tweet in social media. & .127 & .086 & .129 & 1.470 & .143 \\
\hline IPI3: I share a link containing political information. & $-.124-$ & .077 & $-.136-$ & $-1.616-$ & .108 \\
\hline $\begin{array}{l}\text { Homo: I cut off online friendships if they show different } \\
\text { political stands to me. }\end{array}$ & $-.104-$ & .049 & $-.115-$ & $-2.110-$ & .036 \\
\hline $\begin{array}{l}\text { I trust Indonesia's news media by its format: } \\
\text { TM: Magazine }\end{array}$ & $-.040-$ & .101 & $-.030-$ & $-.393-$ & .694 \\
\hline TP:Print & .215 & .104 & .172 & 2.059 & .041 \\
\hline TTV:Television & $-.117-$ & .082 & $-.104-$ & $-1.430-$ & .155 \\
\hline TR:Radio & .033 & .119 & .020 & .280 & .780 \\
\hline Tonline:Online & $-.107-$ & .075 & $-.098-$ & $-1.422-$ & .157 \\
\hline $\begin{array}{l}\text { DF: I have knowledge on how to take online actions } \\
\text { according to the context. }\end{array}$ & .147 & .067 & .130 & 2.197 & .029 \\
\hline
\end{tabular}

PA: Political Attitudes

PP: Political Party Identification

PS : Political Satisfaction

MD: Media Diversity

IPI: Involvement to Political Information
TM: Trust in Magazine

TTV: Trust to Television

TR: Trust to Radio

Tonline: Trust to Online Media

DF: Digital fluency 
Strongly Disagree to the statement: I trust that Basuki Tjahja Purnama is sympathizer of the Indonesian communist party.

\section{Socioeconomic Factors}

The hypotheses for socioeconomic factors are:

H0 Socioeconomic factor does not affect the trust of the public in digital disinformation.

H1 Socioeconomic factor significantly affects the trust of the public in digital disinformation.

Socioeconomic factor consist of level of economy/income in the family, and education. The independent variable is perception to political digital disinformation (PD). Results show that socioeconomic factor relatively affects people's perceptions in political digital disinformation where adjusted $\mathrm{R}^{2}$ is $9 \%$ as indicated in Table 11. The null hypothesis is rejected as $p$ value is 0.001 , which is less than 0.05 as shown in Table 12. Therefore, an alternative hypothesis is accepted.

Table 10.

Model Summary of Socioeconomic Factor

\begin{tabular}{ccccc}
\hline Model & R & R Square & $\begin{array}{c}\text { Adjust. } R \\
\text { square }\end{array}$ & $\begin{array}{c}\text { Std. } \\
\text { Error }\end{array}$ \\
\hline 1 & $.302^{\mathrm{a}}$ & .091 & .071 & .88634 \\
\hline
\end{tabular}

Source: research data.

Note: Predictors: (Constant), Econ, Edu

Table 11.

ANOVA $^{a}$

\begin{tabular}{cccccc}
\hline Model & $\begin{array}{c}\text { Sum of } \\
\text { Squares }\end{array}$ & Df & $\begin{array}{c}\text { Mean } \\
\text { Square }\end{array}$ & F & Sig. \\
\hline Regression & 14.622 & 4 & 3.655 & 4.653 & $.001^{\mathrm{b}}$ \\
\hline
\end{tabular}

Source: research data. Dependent Variable: PD

Note: Predictors: (Constant), Econ, Edu

\section{Political Partisanship}

The hypotheses are:

H0 Political partisanship factor does not affect the trust of the public in digital disinformation.
H1 Political partisanship factor significantly affects the trust of the public in digital disinformation.

Political partisanship consists of political attitudes (PA), party identification (PI) and political satisfaction to incumbent (PS). Results showing that political partisanship factor affects people's perceptions in online disinformation significantly where adjusted $\mathrm{R}^{2}$ is $43 \%$ as indicated in Table 13. The null hypothesis is rejected as $p$ value is 0.000 , which is less than 0.05 as shown in table 14 . Therefore, an alternative hypothesis is accepted.

Table 12.

Model Summary of Political Partisanship

\begin{tabular}{ccccc}
\hline Model & R & R Square & $\begin{array}{c}\text { Adjust. R } \\
\text { square }\end{array}$ & Std. Error \\
\hline 1 & $.676^{\mathrm{a}}$ & .457 & .436 & .69079 \\
\hline
\end{tabular}

Source: Research Data

Note: Predictors: (Constant), PP, PS2, PA3, PS1, PA1, PS3, PA2

Table 13.

ANOVA $^{\mathrm{a}}$

\begin{tabular}{cccccc}
\hline Model & $\begin{array}{c}\text { Sum of } \\
\text { Squares }\end{array}$ & Df & $\begin{array}{c}\text { Mean } \\
\text { Square }\end{array}$ & F & Sig. \\
\hline Regression & 73.417 & 7 & 10.488 & 21.979 & $.000^{\mathrm{b}}$ \\
\hline
\end{tabular}

Source: Research Data

Note: Dependent Variable: PD

Predictors: (Constant), PP, PS2, PA3, PS1, PA1, PS3, PA2

\section{Diversity of Media Exposure}

The hypotheses are:

H0 Media exposure factor does not affect the trust of the public in digital disinformation.

H1 Media exposure factor significantly affects the trust of the public in digital disinformation.

Diversity of media exposure encompasses the diversity of access to media and political stands of accessed media (MD), involvement in political information (IPI), and homophily/ heterophily tendency (Homo). 
Results that pair DV with only the diversity of media exposure factor show that this factor affects people's perceptions in online disinformation relatively, in which adjusted $\mathrm{R}^{2}$ is $10 \%$ as indicated in Table 15 . So this factor is not as influential as political factor. The null hypothesis is rejected as $\mathrm{p}$ value is 0.001 , which is less than 0.05 as shown in Table 16. Therefore, an alternative hypothesis is accepted.

Table 14.

Model Summary of Diversity of Media Exposure

\begin{tabular}{lrrrrr}
\hline Model & R & R Square & $\begin{array}{c}\text { Adjust. } R \\
\text { square }\end{array}$ & Std. Error \\
\hline 1 & $.371^{\mathrm{a}}$ & .138 & .100 & .87267 \\
\hline
\end{tabular}

Note: Predictors: (Constant), MD1, MD2, MD3, MD4, IPI1, IPI2, IPI3, Homo

Table 15.

ANOVA $^{\mathrm{a}}$

\begin{tabular}{cccccc}
\hline Model & $\begin{array}{c}\text { Sum of } \\
\text { Squares }\end{array}$ & Df & $\begin{array}{c}\text { Mean } \\
\text { Square }\end{array}$ & F & Sig. \\
\hline Regression & 22.142 & 8 & 2.768 & 3.634 & $.001^{\mathrm{b}}$ \\
\hline
\end{tabular}

Source: research data. Note. Dependent Variable: $P D$ Predictors: (Constant), Homo, MD3, MI1, MD1, MD4, MI3, MD2, MI2

\section{Trust in Media}

The hypotheses for trust in media factor.

H0 Trust in media factor does not affect the trust of the public in digital disinformation. H1 Trust in media factor significantly affects the trust of the public in digital disinformation.

Results that pair DV with only trust in media factor show that this factor affects people's perceptions in online disinformation relatively, in which adjusted $\mathrm{R}^{2}$ is $9 \%$ as indicated in Table 16. So this factor influence is in the same scale with socioeconomic and diversity of media exposure regarding influence on the DV. The null hypothesis is rejected as $p$ value is 0.000 , which is less than 0.05 as shown in Table 18. Therefore, an alternative hypothesis is accepted.

Table 16.

Model Summary of Trust in Media

\begin{tabular}{ccccc}
\hline Model & $\mathbf{R}$ & R Square & $\begin{array}{c}\text { Adjust. } \\
\text { R square }\end{array}$ & Std. Error \\
\hline 1 & $.340^{\mathrm{a}}$ & .115 & .091 & .87649 \\
\hline
\end{tabular}

Source: research data.

Note: Predictors: (Constant), TOnline, TM, TR, TTV, TP

Table 17.

ANOVA $^{a}$

\begin{tabular}{lccccc}
\hline Model & $\begin{array}{c}\text { Sum of } \\
\text { Squares }\end{array}$ & Df & $\begin{array}{c}\text { Mean } \\
\text { Square }\end{array}$ & F & Sig. \\
\hline Regression & 18.456 & 5 & 3.691 & 4.805 & $.000^{\mathrm{b}}$ \\
\hline
\end{tabular}

Source: research data. Note. Dependent Variable: $P D$

Note: Predictors: (Constant), TOnline, TM, TR, TTV, TP

\section{Digital Fluency}

The hypotheses are:

H0 Digital fluency does not affect the trust of the public in digital disinformation.

H1 Digital fluency factor significantly affects the trust of the public in digital disinformation.

Results that pair DV with only digital fluency factor show that this factor affects people's perceptions in online disinformation relatively, in which adjusted $\mathrm{R}^{2}$ is almost $12 \%$ as indicated in Table 19. So also this factor influence is not as influential as political factor. The null hypothesis is rejected as $p$ value is 0.000 , which is less than 0.05 as shown in Table 20. Therefore, an alternative hypothesis is accepted.

Table 18.

Model Summary of Digital Fluency

\begin{tabular}{lrrrr}
\hline Model & R & R Square & \multicolumn{1}{c}{$\begin{array}{c}\text { Adjust. } \mathrm{R} \\
\text { square }\end{array}$} & Std. Error \\
\hline 1 & $.349^{\mathrm{a}}$ & .122 & .117 & .86418
\end{tabular}

Source: research data

Note: Predictors: (Constant), TOnline, TM, TR, TTV, TP 
Table 19.

ANOVA $^{a}$

\begin{tabular}{cccccc}
\hline Model & $\begin{array}{c}\text { Sum of } \\
\text { Squares }\end{array}$ & Df & $\begin{array}{c}\text { Mean } \\
\text { Square }\end{array}$ & F & Sig. \\
\hline Regression & 19.599 & 1 & 19.599 & 26.243 & $.000^{\mathrm{b}}$ \\
\hline
\end{tabular}

Source: research data.

Note: Dependent Variable: PD

Predictors: (Constant), DF

\section{Discussion}

Recent studies concerning the issue mostly limitedly considered factors from the same category to predict trust or distrust of information. Given the lack of research regarding voters' perceptions towards online disinformation, this study has identified some of the factors drawing from diverse factors rooted from demographic background, political stand, and media issues. In DKI Jakarta's gubernatorial election in 2017, political digital disinformation was used to test the gullibility of respondents in regard to false information about Basuki Tjahja Purnama as a member to Indonesian Communist Party (PKI). The main idea of the research was to observe what factors have actually shaped DKI Jakarta's voters in believing or disbelieving in the disinformation, whether socioeconomic, political partisanship, diversity of media exposure, trust in news media, and digital fluency.

Generally, of all factors, the researcher found that the most significant one was found in political partisanship, while the least one was in socioeconomic. In political partisanship, we intended to prove whether political supports to "Islamic groups or party" might affect the perceptions to online political disinformation in the way that they tend to believe it. Based on the data, the respondents who showed more tolerance to social diversity and were satisfied by the leaderships of Basuki Tjahaja Purnama in economy, public health service and education tended to disbelieve that Basuki was a sympathizer of PKI. To say it in other way, respondents who might have had no prior support of Basuki and the nationalist party were inclined to trust disinformation that was in accordance to their beliefs. On the other hand, socioeconomic status, consisting of levels of income in the family and education, was less likely influence the trust to digital disinformation. The data showed that political partisanship affected people's perception towards news by $45 \%$; while others were influential, ranging in their influence by only $9 \%$ (socioeconomic), 10\% (diversity of media exposure), and $11 \%$ (digital fluency) of $\mathrm{R}$ square.

Regarding the results, to predict which social groups are more gullible to political digital disinformation, we can detect them by seeing to what extent the sameness of perspectives between the pre-existing belief, or value, of the receiving social groups and the underlying political stand of the shared disinformation. For example, if someone has prior credence that the Chinese are closely related to communism, they would be prone to believe that Ahok was a member of the communist party. In other words, people tend to believe any information that confirms their already-held beliefs or bias views.

The diversity of media exposure factors comprised of diversity of accessed media itself and involvement in political information, and homophily/ heterophily tendencies. We found that voters who accessed various media platforms and online contents, loved to share political information to their online network, and maintained the diversity of voices on their online network did not easily believe false information. This result is consistent with Tsfati (2010) who found that the more people distrusted mainstream media, the more likely they were to access alternative online sites. In the context of this study, the respondents diversely accessed all types of media platforms, all kinds of online sites, and even did not hesitate to access news media with a different political opinions from them. 
Trust in media means how far people can perceive the credibility of media. In this research, respondents were asked about their perceptions towards media platforms; namely, magazine, daily, television, radio and online. It seems that the respondents who have more trust in the media are more inclined to disbelieve online false information. The result shows that most respondents have been judging that popular news media platforms were more credible than information shared via social media, instant messaging and taking forms of memes.

Digital fluency is understood as the ability of using acting on digital and online technology in a different context. Gullibility to online hoax has been believed to be related to low digital fluency. This study confirmed that respondents who perceived themselves having higher digital fluency tended to be sceptical to digital disinformation. This is for the reason that they might be competent to criticize, interrogate and compare any information they receive. Thus, respondents in this research, with a higher rate of self-perception on digital fluency did not believe that Ahok had any relations with PKI. Therefore, taken into a wider context, analytical thinking is required to debunk disinformation.

Political disinformation and misinformation are not new to the digital world, but their spread and impact on political processes are tremendous, as seen in the experience of Indonesia's local politics. Based on the research result, the spread of the hoax and severity of the impact might more highly relate to the political partisanship of DKI Jakarta's voters, in contrast to other factors. Having said that, alleviating the spread of political hoax in digital era, for example, by arresting disinformation producers, is not a sufficient measure, as prior political stands play a more important role in the mind of the receivers on believing or disbelieving disinformation.
Considering a wider context of Indonesia, increasing trust to news media, varying media exposure, and improving digital literacy skills might be less effective to prevent believing hoax, than to change the political stands of the Indonesian voters themselves. Although voters could be exposed to various types and content of media or news sources, this will not assure they could grasp a plethora political stands to compare information since cross ownerships of media in Indonesia lead to single political voices in the editorials of conglomerated media. Digital literacy skills of the voters might not be able to prevent them in disbelieving disinformation. Even though they could differentiate a hoax, if the hoax is in accordance to their pre-existing belief, they might believe it. Nevertheless, aforementioned solutions remain relevant to be applied as socioeconomic factor, in this research, did not show significant relations to the gullibility of voters to the digital hoax, meaning that someone better or lesser in educational levels did not indicate their inclination to believe or disbelieve disinformation.

The research result showing that DKI Jakarta's voters who were unlikely to give sympathy to non-Moslem leaders and tended to believe online hoaxes, is actually in accordance with the salient phenomena of intolerance to minority groups like LGBTI, Shia Moslems and Ahmadiyah in other regions of Indonesia (Nugroho, et.al., 2012). Thus, in the context of the presidential election scheduled for 2019, radical and intolerant Islamic views published online could overshadow the rationality of voters, sharpen social segregation, blow the echo chamber, and pose a threat to the credibility and integrity of election committee. A non-corrupt and reform-minded leader could be secondary to the religion, ethnicity and race of the leaders. This seems to be true, as recently Joko Widodo has announced to run for the 2019 presidential candidacy with Ma'ruf Amin, a hard-line cleric and the chairman of Indonesian Ulema Council (MUI). 


\section{Conclusion}

Scholarly attention to the spread of false information through online and digital channels has risen. Although this is an old issue in a new form, and though the internet has existed for more than two decades, this problem has caused social and political turmoil in societies, not to mention in Indonesia.

This research focused on examining the individual or audience level factors that may be related to the spread or anticipation of digital disinformation phenomena. Especially when false information exploits intolerance to ethnic, religious, skin colour groups and identities, its spread and emergence must be contained and anticipated. Therefore, it is crucial to investigate the predicting factors of gullibility, whether it lies on socioeconomic, political partisanship, trust in media, diversity of media exposure or on digital fluency. Based on the study, the last four factors tended to affect the perceptions towards the false information in 2016-17 DKI Jakarta's gubernatorial election. Of those major factors, political partisanship was the most influential factor on predicting gullibility. In this study, political partisanship was defined as the voters' tolerance and satisfaction of a governor who followed a religion other than Islam. The data shows that there was a strong correlation between the political stand and tendency to believe disinformation. This result supports the idea that people might trust disinformation as long as it echoes certain preexisting belief.

This study fills the gap in the scholarship focusing on the perceptions of voters on digital information, which mostly used factors from the same category, while this research took demographic background, political stand, and media issues as considerations in predicting trust or distrust to disinformation. As this study has indicated, further examination should be conducted on the issue of political partisanship formation in relation to perceptions to online disinformation. As information clarifying hoax might be ineffective to change voters' beliefs on disinformation, further studies can investigate the influence of community, peer group, social class, and opinion leaders in the formation and alteration of political partisanship and debunking online disinformation.

\section{References}

Accenture \& Femina. (2016). Getting to Equal: How digital is helping close the gender gap at work. Digital Fluency Indonesia Report. Retrieved from https://www.accenture. com/ t20160506T060137__w__/id-en/_ acnmedia/Accenture/ConversionAssets/ DotCom/Documents/About-Accenture/ PDF/3/AccentureIWD-2016-DigitalFluency-IndonesiaReport.pdf.

Arpan, L. M. \& Raney, A. A. (2003). An experimental investigation of news source and the hostile media effect. JEMC Quarterly, 80(2), 265-281. doi: $10.1177 / 107769900308000203$.

Austin, E. W., \& Dong, Q. (1994). Source v. content effects on judgments of news believability. Journalism \& Mass Communication Quarterly, 71(4), 973-983.

Bologa, R., Lupu, A. R., \& Saba, G. (2007). Digital fluency and its importance in educating young students for the knowledge age. In Congyan, L. (Eds.). Proceedings of the 7th WSEAS International Conference on Distance Learning and Web Engineering (pp. 354-357). Beijing, China: World Scientific and Engineering Academy and Society (WSEAS).

BPS DKI Jakarta. (2015). SUPAS 2015: Profil Kependudukan Hasil SUPAS 2015. Jakarta: BPS DKI Jakarta.

Burgess, S., Sellitto, C., Cox, C. \& Buultjen, J. (2011). Trust perceptions of online travel information by different content creators: some social and legal implications. Information System Frontiers, 13(2), 221-235. Edelman Trust Barometer. (2017). 2017 Edelman Trust Barometer: Global and 
Indonesia. Retrieved from https:// edelman.id/trust2017/wp-content/ uploads/2017/02/2017-Trust-Barometer_ Indonesia_FINAL-VERSION-Share.pdf.

Enns, P. K., \& McAvoy, G. E. (2012). The role of partisanship in aggregate opinion. Political Behaviour, 34(4), 627-651. doi: 10.1007/s11109-011-9176-7

Feldman, L. (2011). Partisan differences in opinionated news perceptions: a test of the hostile media effect. Political Behavior, 33(3), 407-432.

Fico, F., Richardson, J. D., \& Edwards, S. M. (2004). Influence of story structure on perceived story bias and news organization credibility. Mass Communication and Society, 7(3), 301-318.

Fitzgerald, M. A. (1997). Misinformation on the internet: applying evaluation skills to online information. Emergency Librarian, 24(3), 9-14.

Flanagin, A. \& Metzger, M. J. (2000). Perceptions of Internet and Information Credibility, JEMC Quarterly, 77(3), 515-540.

Gaziano, C., \& McGrath, K. (1985). Media Publics and Media Trust. Retrieved from https:// files.eric.ed.gov/fulltext/ED263610.pdf.

Hamid, A. (2014). Jokowi's populism in the 2012 Jakarta Gubernatorial Election. Journal of Current Southeast Asian Affairs, 33(1), 85-109.

Hendrie, G. A.,Coveney, J., \& Cox, D. (2008). Exploring nutrition knowledge and the demographic variation in knowledge levels in an Australian community sample. Public Health Nutrition, 11(12), 1365-1371 doi:10.1017/S1368980008003042

Houston, B., Hansen, G. J., \& Nisbett, G. S. (2011). Influence of user comments on perceptions of media bias and thirdperson effect in online news. Electronic News, 5(2), 79-92.

Hutabarat, D. (2018). Berita hoaxakan diumumkan di laman Kominfo, kenali ciri-cirinya. Retrieved from https://kominfo.go.id/ content/detail/14708/berita-hoax-akandiumumkan-di-laman-kominfo-kenaliciri-cirinya/0/sorotan_media.

Hutchinson, W. (2006). Information warfare and deception. Informing Science Institute, 9, 213-223.

Jang, S. M. (2013). Seeking congruency or incongruency or in online? examining selective exposure to four controversial science issues. Science Communication, 36(2), 143-167.

Johnson, T. J., \& Kaye, B. K. (2009). In blog we trust? deciphering credibility of components of the internet among politically interested internet users. Computers in Human Behavior, 25(1), 175182.

Kato, H. (2017). The challenge to religious tolerance: fundamentalits' resistance to a non-muslim leader in Indonesia. Comparative Civilizations Review, 77(77), 77-89.

Kiousis, S. (2001). Public trust or mistrust? perceptions of media credibility in the information age. Mass Communication and Society, 4(4), 381-403.

Kohring, M. \& Matthes, J. (2007). Trust in media development and validation of a multidimensional scale. Communication Research, 34(2), 231-252.

Kwok, Y. (2017, January 6). Where memes could kill: Indonesia's worsening problem of fake news. Time.com. Retrieved from http://time.com/4620419/indonesia-fakenews-ahok-chinese-christian-islam/.

Ladd, J. M. (2010). The role of media distrust in partisan voting. Political Behavior, 32(4), 567-583.

Lee, T. T. (2005). The liberal media myth revisited: an examination of factors influencing perceptions of media bias. Journal of Broadcasting $\mathcal{E}$ Electronic Media, 49(1), 43-64.

Lee, T. T. (2010). Why they don't trust the media: an examination of factors predicting 
trust. American Behavioral Scientist, 54(1), 8-21.

Lindsey, T. (2018). Rise of conservative Islam in Indonesia. Australian Institute of International Affairs. Retrieved from https://www.internationalaffairs.org.au/ australianoutlook/jokowis-deputy-pickconfirms-rise-of-conservative-islam-inindonesia/.

Mahtani, M. (2008). Racializing the audience: Immigrant perceptions of mainstream Canadian English Language TV News. Canadian Journal of Communication, 33(4). doi:10.22230/cjc.2008v33n4a2030

Metzger M. J., Flanagin, A. J., Eyal, K., Lemus, D. R., \& Mccann, R. M. (2003). Credibility for the 21st century: integrating perspectives on source, message and media credibility in the contemporary media environment. In P. J. Kalbfleisch (Eds.), Communication Yearbook 27 (pp. 293-335). Mahwah, New Jersey, US: Lawrence Erlbaum Associates, Inc., Publishers.

Miller, C., \& Bartlett, J. (2012). 'Digital Fluency': towards young people's critical use of the internet. Journal of Information Literacy, 6(2), 35-55.

Miichi, K. (2014). The role of religion and ethnicity in Jakarta's 2012 gubernatorial election. Journal of Current Southeast Asian Affairs, 33(1), 55- 83.

Nichols, C., McKinnon, L., \& Geary, A. (2016). Rumor has it: examining the effects of facebook addiction on political knowledge gullibility. The Journal of Social Media in Society, 5(1), 229-264.

Novitasari, S. C. (2017, April 21). Isu SARA, cara ampuh menggerus Ahok-Djarot. CNN. Retrieved from http://www. cnnindonesia.com/kursipanasdki1/ 20170421112806-521-209209/isu-saracara-ampuh-menggerus-ahok-djarot/

Nugroho, I. (2017, April 21). Sentimen agama dan blunder Ahok. Detik.com. Retrieved from https://x.detik.com/detail/
investigasi/20170421/Sentimen-Agamadan-Blunder-Ahok/index.php

Nugroho, Y., Nugraha, L. K., Laksmi, S., Amalia, M., Putri, D. A., \& Amalia, D. (2012). Media and the vulnerable in Indonesia: Accounts from the margin (Report Series: Engaging Media, Empowering Society: Assessing media policy and governance in Indonesia through the lens of citizens' rights. Research collaboration of Centre for Innovation Policy and Governance and HIVOS Regional Office Southeast Asia, funded by Ford Foundation). Jakarta: CIPG and HIVOS.

Qazvinian, V., Rosengren, E., Dragomir, R., \& Qiaozhu, R. (2011). Rumor has it: identifying misinformation in microblogs. Proceedings of the 2011 Conference on Empirical Methods in Natural Language Processing (pp. 1589-1599). Edinburg, Scotland, UK: Association for Computational Linguistics.

Renard, J. B. (2007). Denying rumours. Diogenes, 54(1), 43-58.

Ritzhaupt, A. D., Liu, F., Dawson, K., \& Barron, A. E. (2013). Differences in student information and communication technology literacy based on socioeconomic status, ethnicity, and gender. Journal of Research on Technology in Education, 45(4), 291-307. doi:10.1080/15 391523.2013.10782607

Schmitt, K. M., Gunther, A. C., \& Liebhart, J. L. (2004). Why partisan see mass media as biased. Communication Research, 31(6), 623-641.

Setijadi, C. (2017). The Jakarta Election Continues: What Next for Embattled Governor Ahok? Perspective. Retrieved from https://iseas.edu.sg/images/pdf/ ISEAS_Perspective_2017_18.pdf.

Shatz, M., Diesendruck, G., Martinez-Beck, I., \& Akar, D. (2003). The influence of language and socioeconomic status on 
childrens understanding of false belief. Developmental Psychology, 39(4), 717-729. doi:10.1037/0012-1649.39.4.717

Sheth, D. L. (1971). Partisanship and political development. Economic and Political Weekly, 6(3/5), 259$261+263+265+267+269+271+273-274$.

Shin, J., Jian, L., Driscoll, K. \& Bar, F. (2016). Political rumoring on twitter during the 2012 us presidential election: rumor diffusion and correction. New Media and Society, 19(8), 1214-1235.

Suaedy, A. (2014). The role of volunteers and political participation in the 2012 Jakarta gubernatorial election. Journal of Current Southeast Asian Affairs, 33(1), 111-138.

Thorson, E. (2016). Belief Echoes: the persistent effects of corrected misinformation. Political Communication, 3(3), 460-480.

Tran, H. (2013). Does exposure to online media matter? the knowledge gap and the mediating role of news use. International Journal of Communication, 7(1), 831-852.

Tsfati, Y., \& Cappella, J. N. (2005). Why do people watch news they do not trust? the need for cognition as a moderator in the association between news media scepticism and exposure. Media Psychology, 7(3), 251-271.

Tsfati, Y. (2010). Online news exposure and trust in the mainstream media: exploring possible associations. American Behavioral Scientist, 54(1), 22-42.

Vltchek, A. (2017). 52 Years after fascist genocide, Indonesians scared of "Communist Ghosts": from Jakarta and Yogyakarta. Global Research. Retrieved from https:// www.globalresearch.ca/52-years-afterfascist-genocide-indonesians-scared-ofcommunist-ghosts/5612709.

Vreese, C.H., \&Neijens, P.(2016). Measuring media exposure in a changing communications environment. Communication Methods and Measures, 10(2-3), 69-80. doi: 10.1080/19312458.2016.1150441

Wang, E., Myers, M. D., \& Sundaram, D. (2012). Digital natives and digital immigrants: towards a model of digital fluency. European Conference on Information Systems (ECIS) 2012 Proceedings. Spain: Association for Information Systems AIS Electronic Library (AISeL).

Watts, M. D., Domke, D., Shah, D. V., \& Fan, D.P. (1999). Elite cues and media bias in presidential campaigns: Explaining public perceptions of a liberal press. Communication Research, 26(2), 144-175. doi: 10.1177/009365099026002003

White, J. \& Ypi, L. (2011). On partisan political justification. American Political Science Review, 105(2), 381-396. doi: 10.1017/ s0003055411000074

White, G.K. (2013). Digital fluency: skills necessary for learning in the digital age. Retrieved from https://research.acer.edu. au/digital_learning/6/.

Williams, A. E. (2012). Trust or bust?: Questioning the relationship between media trust and news attention. Journal of Broadcasting \& Electronic Media, 56(1),116131. doi: $10.1080 / 08838151.2011 .651186$

Williams, D.R., Yu, Y., Jackson, J.S., \& Anderson, N.B. (1997). Racial differences in physcial and mental helath: Socio-economic status, stress, and discrimination. Journal of Health Psychology, 2(3), 335-351. doi: 10.1177/135910539700200305

Yang, K. C. C. (2007). Factors influencing internet users' perceived credibility of news-related blogs in Taiwan. Telematics $\mathcal{E}$ Informatics, 24, 69-85. doi: 10.1016/j. tele.2006.04.001.

Yee, A. (2017). Post-truth politics and fake news in Asia. Global Asia, 12(2), Summer 2017. 